\title{
Brachyuran Crab Fauna Character Estimated from Marine Water of Bangladesh and Noted New Record (Crustacea: Decapoda) as Distribution
}

\author{
Nur Alam¹, Sanjay Chakraborty', Md. Muzammel Hossain', Mohammad Abdul Baki1*, \\ Shayer Mahmood Ibney Alam ${ }^{1}$, Chenhong Li² \\ ${ }^{1}$ Department of Zoology, Faculty of Life and Earth Science, Jagannath University, Dhaka, Bangladesh \\ ${ }^{2}$ Shanghai Universities Key Laboratory of Marine Animal Taxonomy and Evolution, College of Fisheries and Life Science, \\ Shanghai Ocean University, Shanghai, China \\ Email: ^mabaki@gmail.com
}

How to cite this paper: Alam, N., Chakraborty, S., Hossain, Md.M., Baki, M.A., Alam, S.M.I. and Li, C.H. (2020) Brachyuran Crab Fauna Character Estimated from Marine Water of Bangladesh and Noted New Record (Crustacea: Decapoda) as Distribution. Open Journal of Marine Science, 10, 218-232.

https://doi.org/10.4236/ojms.2020.104017

Received: June 29, 2020

Accepted: September 27, 2020

Published: September 30, 2020

Copyright $\odot 2020$ by author(s) and Scientific Research Publishing Inc. This work is licensed under the Creative Commons Attribution International License (CC BY 4.0).

http://creativecommons.org/licenses/by/4.0/

\begin{abstract}
As habitat and distribution, in the study a total of $18 \mathrm{crab}$ species were identified, belonging to 10 families (Calappidae, Epialtidae, Gecarcinidae, Grapsidae, Matutidae, Ocypodidae, Panopeidae, Sesarmidae, Varunidae, and Xanthidae) order Decapoda under subphylum crustacean with relevant distinguish morphological and meristic character and geographical position. We investigated crab species of Bangladesh from December 2013 to October 2014. All species samples were collected by hand picking on a baseline survey in Saint Martin's Island (the only coral island of Bangladesh) and adjacent marine water body of Bay of Bengal, Satkhira area (brackish and freshwater) and mangrove forest area (Sundarban). Among 18 species, $10 \mathrm{crab}$ species from Family Epialtidae (1 species), Gecarcinidae (2 species), Ocypodidae (1 species), Panopeidae (1 species), Sesarmidae (1 species) and Xanthidae (4 species) were newly occurred in the Bay of Bengal, Bangladesh. Cardisoma armatum and Zosymus aeneus species were larger than other enlisted species.
\end{abstract}

\section{Keywords}

Crab Species, Morphology, Distribution, Coral Island, Bangladesh

\section{Introduction}

Intertidal area is an important environment that is challenging for living organisms in Saint Martin Island. Marine organisms are affected by humans because 
of this area's easy accessibility whereas meeting land and sea [1]. The rocky intertidal area is one of the physically particularly extreme environments around the sea area. Brachyuran crabs belonging to the Order Decapoda are the most diverse animal of crustaceans [2]. In the world, the infra class Brachyura contains about 70 families under Decapoda [3]. In India, a total of 226 species of brachyuran crabs belonging to 130 genera and 39 families reported from different maritime states of the west coast [4]. According to marine species identification portal a total of 1250 species and subspecies of brachyuran crabs recorded from Japan [5]. As aquaculture and traditional food, crab fishery has an important economic value around Asia and in Bangladesh. In the aquatic habitat crustaceans are the most abundant and diverse group. Last decades many researches from different parts of the world focused on taxonomic decapod crustaceans that have enriched crab list and biodiversity [6] [7] [8] but study on crab in marine water very limited research has been done in Bangladesh. This country is a data deficit area in marine crab taxonomic field which leads to limited contribution into the world crab taxonomic and distribution area. Very few researchers have done the taxonomic study on crab [9], freshwater crab in some wetland ecosystem [10], crab in coast and estuary [11] and some marine crab from the Bay of Bengal in Bangladesh [12]. Thus, taxonomic with distribution study has not been widely reported yet from Bay of Bengal marine water. However, the aim of the present investigation is to increase the knowledge on the brachyura fauna family, wise species identification from mainly Bay of Bengal and freshwater of Saint Martin's Island and mangrove forest area in Bangladesh.

\section{Materials and Methods}

\subsection{Study Area, Sites and Time}

In the study, we investigated at five sites of Bangladesh. Selected study area is Saint Martin's Island and adjacent water bodies of Bay of Bengal, Sathkhira, and Sundarban for crab survey (Figure 1). Live coral sites were selected for a survey in Saint Martin's Island. Site 1: This area was covered by the sandy, rocky, and sandy-rocky beach. Site 2: Freshwater ditch is containing marsh. Site 3: Marine water is a stony area and deep $60 \mathrm{~m}$ from the surface. Site 4: Satkhira area (brackish and freshwater), mainly Maloncho river dam of Munshiganj union, Shyamnagar, Site 5: Sundarban (mangrove forest area), mainly Dublarchar, Sundarban, Bangladesh. This study was investigated and collected all samples during December 2013 to October 2014.

\subsection{Sample Collection and Preservation Procedure}

Crab samples were collected by hand picking from beach and fish landing centers, and some were obtained from fishermen. Several samples were collected from fishing nets in shallow coastal areas and the deep sea. The samples were washed with pure water after collecting, preserved and photo session. Photographs of the crabs were taken by Nikon USA D3300 digital SLR Camera before 


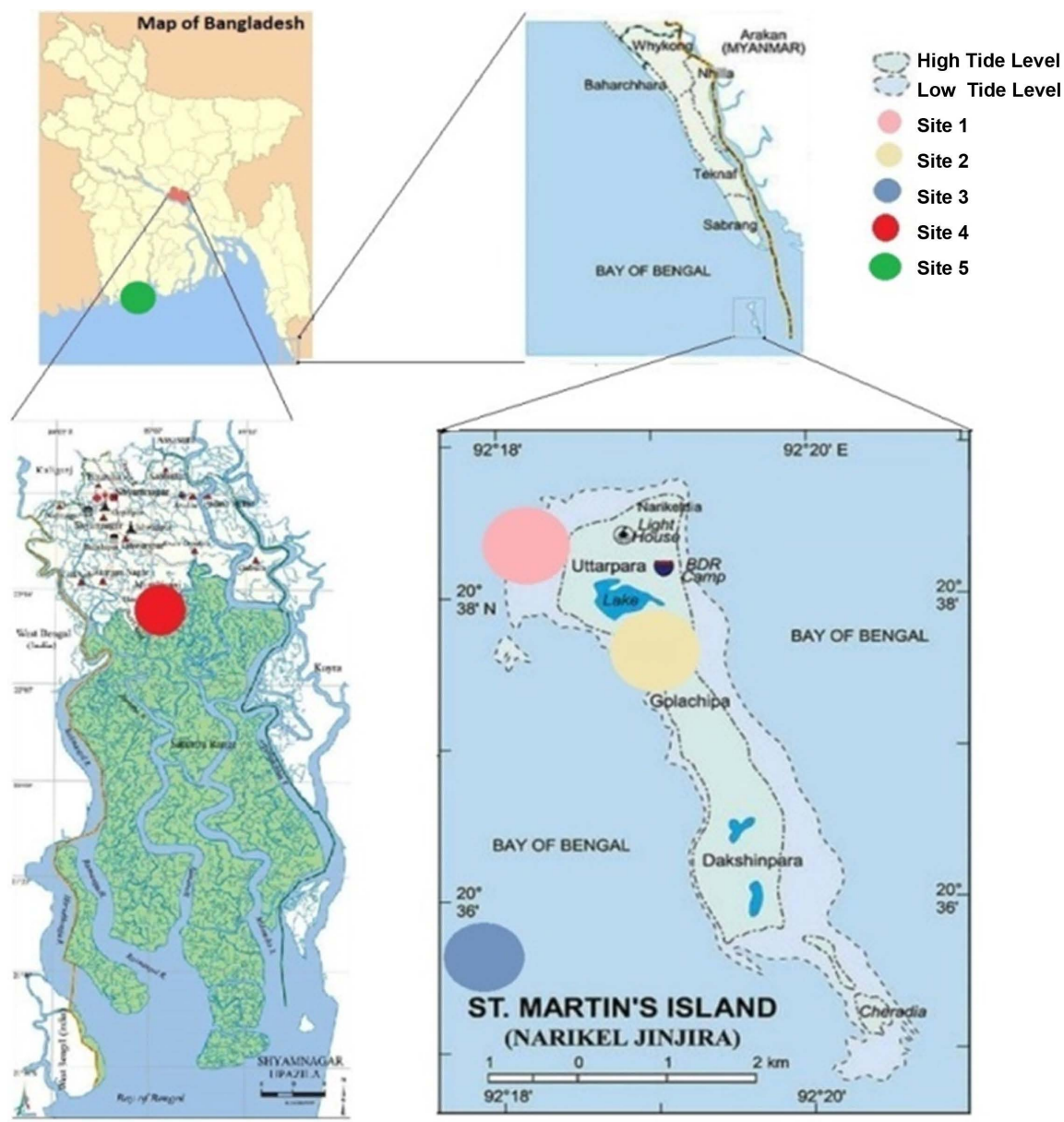

Figure 1. Showed the study sites for brachyuran crab fauna of Bangladesh.

their color changed. Fresh specimens were separated and placed in the ice box for preservation. All specimens were carried out to the fisheries Lab, Department of Zoology, Jagannath University. After observations and measurements, specimens were reserved and preserved with $6 \%-10 \%$ formalin in the Zoological Museum of Jagannath University, Dhaka.

\subsection{Species Measurement, Identification and Analysis}

All morphological and meristic characteristics were measured by the digital calipers scale as millimeter $(\mathrm{mm})$ [13]. Species were identified using pictorial, diagnostic characters as well as morphological and meristic characteristics such as color of body part, external features, shape of the carapace, dorsal surface, cheliped and legs, shape of anterolateral margins, antennule and antenna, eye shape, and pereiopod [14]. The following the references for the species identification [4] [9] [15]-[27]. Few species establish local names according to origin. Then, the identified species were tagged with a zoological certain number. To establish present distribution of the crab species is based on field survey, all available reference, and data from various biodiversity databases in addition to SeaLifeBase (https://www.sealifebase.ca), Marine Species Identification Portal (MSIP) 
(http://species-identification.org/index.php). All the particular references are mentioned in the above databases. Discrepancies in nomenclature were sorted following the World Register of Marine Species. All measurement data were inputted in the Microsoft excel 2010 data sheet timely and analyzed. Graph figures were plotted by using SigmaPlot 12.0.

\section{Results and Discussion}

In the study, a total of $18 \mathrm{crab}$ species recorded belongs to 10 families (Calappidae, Epialtidae, Gecarcinidae, Grapsidae, Matutidae, Ocypodidae, Panopeidae, Sesarmidae, Varunidae, and Xanthidae) order Decapoda under subphylum crustacean. As a result of distribution, nine crab species were recent newly added to the crab list of Bangladesh. Major Morphometric and meristic key of crab species were estimated as millimeter scales that are represented in Table 1 and Table 2, and Figure 2 and Figure 3 for species identification and calculation.

Table 1. Estimated weight and morphometric characters of crab species that recorded from marine water of Bangladesh.

\begin{tabular}{|c|c|c|c|c|c|c|}
\hline \multirow{2}{*}{ Family } & \multirow{2}{*}{ Scientific Name } & \multirow{2}{*}{ Local Name } & \multirow{2}{*}{ Sites } & \multirow{2}{*}{$\mathrm{W} / \mathrm{Cl} / \mathrm{Cb} / \mathrm{Al} / \mathrm{Anl} / \mathrm{esl} / \mathrm{ed} / \mathrm{pbl} / \mathrm{fml}$} & \multirow{2}{*}{$\begin{array}{l}\text { Left Cheliped } \\
(\mathrm{mm})\end{array}$} & \multirow{2}{*}{$\begin{array}{l}\text { Right Cheliped } \\
(\mathrm{mm})\end{array}$} \\
\hline & & & & & & \\
\hline Calappidae & Calappa lophos & Banksho Kankra & 1 & $25 / 50 / 70 / 4 / 6 / 3 / 3 / 0 / 0$ & $4 / 6 / 19 / 14 / 22 / 12$ & $4 / 6 / 19 / 14 / 22 / 12$ \\
\hline Epialtidae & Criocarcinus superciliosus & Makorsa Kankra & 3 & $15.87 / 56 / 38 / 8 / 14 / 5 / 1 / 6 / 7$ & $6 / 11 / 17 / 10 / 20 / 7$ & $6 / 11 / 17 / 10 / 20 / 7$ \\
\hline Gecarcinidae & Cardisoma armatum & Baki Kankra & 2 & $174 / 60 / 80 /-/-/ 8 / 4 / 25 / 19$ & $9 / 8 / 31 / 2 / 64 / 35$ & $12 / 15 / 28 / 22 / 55 / 32$ \\
\hline Gecarcinidae & Cardisoma carnifex & Ragi Kankra & 2 & $73.77 / 44 / 57 / 6 / 4 / 8 / 4 / 20 / 13$ & $9 / 14 / 22 / 18 / 67 / 28$ & $10 / 15 / 24 / 20 / 73 / 30$ \\
\hline Grapsidae & Grapsus albolineatus & Chironi Kankra & 1 & $1.4 / 14 / 16 / 3 /-/ 3 / 2 / 10 / 4$ & $1 / 2 / 5 / 3 / 6 / 4$ & $1 / 2 / 5 / 3 / 6 / 4$ \\
\hline Matutidae & Matuta lunaris & Lunari Kankra & 1 & $6.2 / 26 / 40 / 8 /-/ 3 / 0.8 / 6 / 6$ & $1.5 / 4 / 8 / 8 / 18 / 8$ & $1.5 / 4 / 8 / 8 / 18 / 8$ \\
\hline Ocypodidae & Ocypode pallidula & BGB Kankra & 1 & $3.9 / 19 / 20 /-/-/ 3 / 2 / 12 / 3$ & $2 / 4 / 8 / 5 / 9 / 6$ & 2/5/9/8/15/9 \\
\hline Ocypodidae & Ocypode macrocera & Lal Kankra & 1 & $16.18 / 28 / 26 /-/-/ 6 / 4 / 19 / 4$ & $3 / 11 / 18 / 14 / 28 / 16$ & $3 / 11 / 18 / 14 / 28 / 16$ \\
\hline Ocypodidae & Uca rosea & Lalpa Kankra & 4 & $1.02 / 10 / 18 /-/-/ 4 / 2 / 7 / 2$ & $1 / 3 / 8 / 5 / 20 / 10$ & $1 / 2 / 6 / 3 / 5 / 4$ \\
\hline Panopeidae & Panopeus lacustris & Badami Kankra & 1 & $2.52 / 16 / 24 /-/-/ 2 / 2 / 4 / 9$ & $4 / 5 / 7 / 4 / 14 / 7$ & $4 / 5 / 7 / 4 / 14 / 7$ \\
\hline Sesarmidae & Pseudosesarma bocourti & Gombuj Kankra & 2 & $20.8 / 28 / 31 / 2 / 5 / 5 / 3 / 13 / 17$ & $8 / 12 / 5 / 8 / 36 / 16$ & $8 / 12 / 5 / 8 / 36 / 16$ \\
\hline Sesarmidae & Episesarma $s p$ & Bang kankra & 2 & $2.56 / 18 / 18 /-/-/ 3 / 2 / 8 / 8$ & $1 / 4 / 6 / 3 / 8 / 5$ & $1 / 4 / 6 / 3 / 8 / 5$ \\
\hline Varunidae & Varuna litterata & $\begin{array}{l}\text { Gulli Kankra, } \\
\text { Chiti Kankra }\end{array}$ & 2 & $12 / 33 / 32 / 10 / 9 / 3 / 2 / 18 /-$ & $5 / 5 / 10 / 8 / 18 / 10$ & $5 / 5 / 10 / 8 / 18 / 10$ \\
\hline Xanthidae & Atergatis floridus & Mojaik kankra & 3 & $67.9 / 45 / 62 / 9 / 7 / 3 / 3 / 16 / 11$ & $11 / 11 / 16 / 21 / 35 / 24$ & $11 / 11 / 16 / 21 / 35 / 24$ \\
\hline Xanthidae & Atergatis integerrimus & Mishuk Kakra & 3 & $12 / 29 / 40 / 5 / 3 / 2 / 1 / 8 / 10$ & $3 / 4 / 10 / 11 / 16 / 9$ & $3 / 4 / 10 / 11 / 16 / 9$ \\
\hline Xanthidae & Lophozozymus pictor & $\begin{array}{l}\text { Sada fota shila } \\
\text { kankra }\end{array}$ & 3 & $150 / 56 / 89 / 10 / 7 / 2 / 2 / 20 / 18$ & $11 / 15 / 24 / 28 / 45 / 27$ & $11 / 15 / 24 / 28 / 45 / 27$ \\
\hline Xanthidae & Xantho poressa & Sabuj Kankra & 1 & $59 / 11 / 16 /-/-/ 2 / 2 / 3 / 5$ & $1 / 3 / 4 / 6 / 10 / 5$ & $1 / 3 / 4 / 6 / 10 / 5$ \\
\hline Xanthidae & Zosymus aeneus & Bishakto Kankra & 3 & $181.88 / 68 / 88 / 13 / 6 / 3 / 2 / 18 / 18$ & $15 / 18 / 37 / 36 / 66 / 35$ & $18 / 16 / 22 / 21 / 44 / 24$ \\
\hline
\end{tabular}

Note: here, $\mathrm{W}=$ weight, $\mathrm{Cl}=$ carapace length, $\mathrm{Cb}=$ carapace breadth, $\mathrm{Al}=$ antennule length, $\mathrm{Anl}=$ antenna length, esl $=$ eye stalk length, ed $=$ eye diameter, $\mathrm{pbl}=$ posterior border length, $\mathrm{fml}=$ frontal margin length, $\mathrm{A}=\mathrm{Coxa}, \mathrm{B}=\mathrm{Basi}$ - ischium, $\mathrm{C}=\mathrm{Merus}, \mathrm{D}=\mathrm{Carpus}, \mathrm{E}=\mathrm{Propodus}, \mathrm{F}=\mathrm{Dactylus}$. (mm scale). 
Table 2. Estimated meristic characters of crab species that recorded from marine water of Bangladesh.

\begin{tabular}{|c|c|c|c|c|c|c|c|}
\hline \multirow{3}{*}{ Scientific Name } & \multirow{3}{*}{ Ans/Pob/Fs/Ife/Nt } & \multirow{2}{*}{ Leg } & \multirow{2}{*}{ Cheliped } & \multicolumn{4}{|c|}{ Periopod } \\
\hline & & & & 2nd & 3 rd & 4th & 5th \\
\hline & & $\mathrm{m} / \mathrm{C} / \mathrm{D}$ & $\mathrm{Bi} / \mathrm{m} / \mathrm{C} / \mathrm{D} / \mathrm{P}$ & $\mathrm{Bi} / \mathrm{m} / \mathrm{C} / \mathrm{D} / \mathrm{P}$ & $\mathrm{Bi} / \mathrm{m} / \mathrm{C} / \mathrm{D} / \mathrm{P}$ & $\mathrm{Bi} / \mathrm{m} / \mathrm{C} / \mathrm{D} / \mathrm{P}$ & $\mathrm{Bi} / \mathrm{m} / \mathrm{C} / \mathrm{D} / \mathrm{P}$ \\
\hline Calappa lophos & xiii pairs/-/-/-/- & & & & & & \\
\hline Criocarcinus superciliosus & $\mathrm{v}$ pairs/i spine/ii/Ii/- & $\mathrm{i} / \mathrm{i} /-$ & $-/ \mathrm{ii}-/-/-$ & & & & \\
\hline Cardisoma armatum & i pair/-/-/-/xv + xiv & & -/ii/-/-/ii & $\begin{array}{l}\text { 0/0/0/xviii/iv } \\
\text { 0/0/0/xviii/iv }\end{array}$ & $\begin{array}{l}\text { 0/0/0/xviii/ii } \\
0 / 0 / 0 / \text { xviii/ii }\end{array}$ & $\begin{array}{l}0 / 0 / 0 / \text { xiv/ii } \\
0 / 0 / 0 / \text { xiv/ii }\end{array}$ & $\begin{array}{l}0 / 0 / 0 / \mathrm{xx} / 0 \\
0 / 0 / 0 / \mathrm{xx} / 0\end{array}$ \\
\hline Cardisoma carnifex & i pair/-/-/-/xvii + xviii & & -/xxxvii/i/-/- & & & & \\
\hline Grapsus albolineatus & ii pairs/-/-/-/viii + vii & $\mathrm{Iv} / \mathrm{i} / \mathrm{i}$ & $-/ v / i /-/ i x$ & 0/i/0/xiii & 0/i/0/xii/0 & $0 / \mathrm{i} / 0 / \mathrm{xv} / 0$ & 0/i/0/xiii/0 \\
\hline Matuta Iunaris & iv pairs/-/Ii/-/vii + vii & & -/Vii/i/-/iv & $\mathrm{v}$ spines & $\mathrm{v}$ spines & $\mathrm{v}$ spines & \\
\hline Ocypode pallidula & $-/-/-/-/ v i+v i$ & $-/ \mathrm{i} /-$ & -/Vii/i/Xiv/- & & & & \\
\hline Ocypode macrocera & Many/-/-/Many/vi + vi & & $-/ x x / v i i / x / x x v$ & few & few & viii spines & \\
\hline Uca rosea & i pair/-/-/-/xiv + xiv & & & & & & \\
\hline Panopeus lacustris & iii pairs/-/-/-/iii + iii & & & & & & \\
\hline Pseudosesarma bocourti & i pairs/-/-///ix $+x$ & & Xxxi/ii/vi/-/- & $0 / \mathrm{i} / 0 / 0 / 0$ & $0 / \mathrm{i} / 0 / 0 / 0$ & $0 / \mathrm{i} / 0 / 0 / 0$ & $0 / \mathrm{i} / 0 / 0 / 0$ \\
\hline Episesarma $s p$ & ii pair/-/-/-/iii + iii & & $-/ \mathrm{i} / \mathrm{ii} /-/-$ & $0 / \mathrm{i} / 0 / 0 / 0$ & $0 / \mathrm{i} / 0 / 0 / 0$ & $0 / \mathrm{i} / 0 / 0 / 0$ & $0 / \mathrm{i} / 0 / 0 / 0$ \\
\hline Varuna litterata & iii pairs/-/-/-/vii + viii & $\mathrm{i} / \mathrm{i} /-$ & -/ii/ii/-/- & & & & \\
\hline Atergatis floridus & $-/-/-/-/ v+$ vii & & & & & & \\
\hline Atergatis integerrimus & $-/-/-/-/ \mathrm{iv}+\mathrm{iii}$ & & $-/-/ \mathrm{i} /-/-$ & & & & \\
\hline Lophozozymus pictor & iii pairs/-/-/-/viii + vii & & $-/-/ \mathrm{Ii} /-/-$ & & & & \\
\hline Xantho poressa & iii pairs/-/-/-/0 + ii & & & & & & \\
\hline Zosymus aeneus & iv pairs/-/Iv/i spine/v + vi & $\mathrm{v} /-/-$ & $-/ \mathrm{v} / \mathrm{i} /-/-$ & & & & \\
\hline
\end{tabular}

Notes: Ans = anterolateral spine; Pob = posterior border; Fs = frontal spine; Ife = in front of eye; $\mathrm{Nt}=$ number of teeth; $\mathrm{m}=\mathrm{merus} ; \mathrm{C}=$ carpus; $\mathrm{D}=$ dactylus; $\mathrm{Bi}=$ basi-ischium; $\mathrm{p}$ = propodus.

\subsection{Estimated Weight and Morphometric Character}

Among all crab species maximum wet weight was $181.88 \mathrm{~g}$ for the crab species Zosymus aeneus. Carapace length and breadth measured as a major identification key that observed maximum length $68 \mathrm{~mm}$ and breadth $88 \mathrm{~mm}$ in $Z$. aeneus. Posterior border length: $18 \mathrm{~mm}$; frontal margin length: $18 \mathrm{~mm}$; antennule length: $13 \mathrm{~mm}$; antenna length: $6 \mathrm{~mm}$; eye stalk length: $3 \mathrm{~mm}$; eye diameter: 2 mm (Table 1).

\subsection{Estimated Cheliped and Pereiopod}

Each crab species has two (left and right) cheliped (Table 1). Pereiopod is a key character of the leg of the crab species and it includes six parts that are represented in Figure 2 and Figure 3.

Coxa: Its small segment of the leg that connects to the body. This is the first part of cheliped and pereiopod from the body of crab species. In cheliped, maximum size of coxa was $15 \mathrm{~mm}$ (left) and $18 \mathrm{~mm}$ (right) recorded whereas in pereiopod coxa average size was $9.25 \pm 2.98 \mathrm{~mm}$ for $Z$. aeneus. 

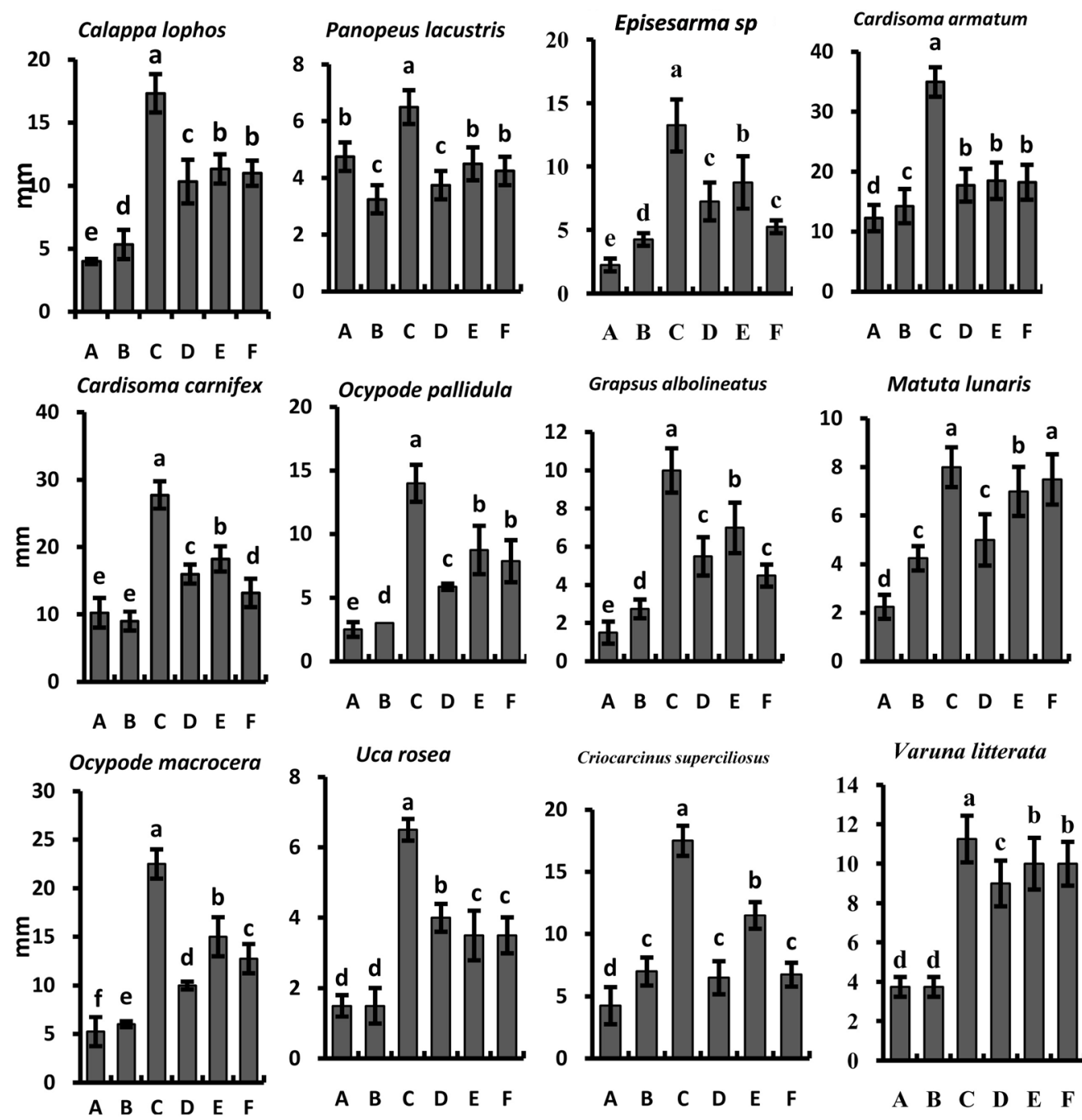

Figure 2. Estimated average morphological character of different part of Pereiopod of crab species that recorded from marine water of Bangladesh (here, $\mathrm{A}=$ Coxa, $\mathrm{B}=\mathrm{Basi}$ - ischium, $\mathrm{C}=$ Merus, $\mathrm{D}=$ Carpus, $\mathrm{E}=$ Propodus, $\mathrm{F}=$ Dactylus) (mm scale). (Different small letter indicated significantly different between body parts at $\mathrm{P}<0.05)$.

Basi-ischium: Its second part that situate between coxa and merus in cheliped and pereiopod of crab species. In cheliped, large size of basi-ischium was $18 \mathrm{~mm}$ (left) and $16 \mathrm{~mm}$ (right) whereas in pereiopod average size was $14.25 \pm 2.87 \mathrm{~mm}$ present in C. armatum.

Merus: Its third part that situate between basi-ischium and carpus in cheliped and pereiopod of crab species. In cheliped, maximum size of merus is $37 \mathrm{~mm}$ (left) for $Z$. aeneus and $28 \mathrm{~mm}$ (right) for $C$. armatum whereas in pereiopod, maximum average size was $35.00 \pm 2.44 \mathrm{~mm}$ recorded from $C$. armatum.

Carpus: As the 4th part of cheliped and pereiopod, its position between merus and propodus in cheliped and pereiopod of crab species. In cheliped, maximum size was $36 \mathrm{~mm}$ (left) for $Z$. aeneus and $22 \mathrm{~mm}$ (right) for $C$. armatum but in pereiopod average maximum size of carpus $20.25 \pm 0.50 \mathrm{~mm}$ recorded from $\mathrm{Lo}$ phozozymus pictor. 

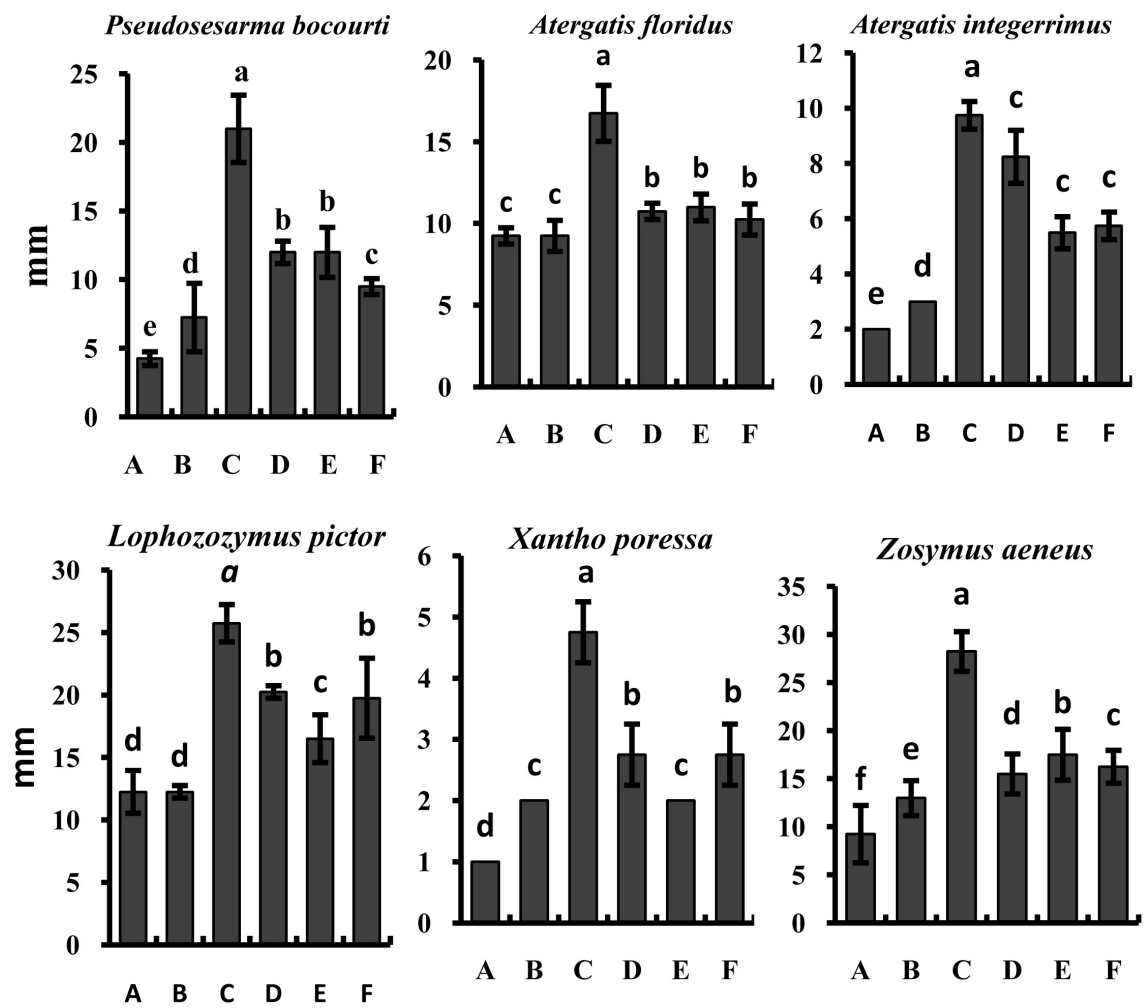

Figure 3. Estimated average morphological character of different part of Pereiopod of crab species that recorded from marine water of Bangladesh (here, $\mathrm{A}=\mathrm{Coxa}, \mathrm{B}=\mathrm{Basi}$ ischium, $\mathrm{C}=$ Merus, $\mathrm{D}=$ Carpus, $\mathrm{E}=$ Propodus, $\mathrm{F}=$ Dactylus) $(\mathrm{mm}$ scale). (Different small letter indicated significantly different between body parts at $\mathrm{P}<0.05$ ).

Propodus: Its 5th part of cheliped and pereiopod that position between carpus and dactylus in cheliped and pereiopod of crab species. In cheliped, height size of propodus was $67 \mathrm{~mm}$ (left) and $73 \mathrm{~mm}$ (right) for C. carnifex whereas average highest size of propodus was $18.50 \pm 3.03 \mathrm{~mm}$ in pereiopod of $C$. armatum.

Dactylus: Its last part of cheliped and pereiopod that join with only propodus in cheliped and pereiopod of crab species. In cheliped, maximum size of dactylus was $35 \mathrm{~mm}$ (left) and $32 \mathrm{~mm}$ (right) for $C$. armatum whereas average maximum size was $19.75 \pm 3.20 \mathrm{~mm}$ in pereiopod of Lophozozymus pictor.

\subsection{Estimated Meristic Character}

We measured the meristic characters of $18 \mathrm{crab}$ species in Table 2. Large species C. armatum, counted anterolateral spine: i pair; number of teeth: $\mathrm{xv}+\mathrm{xiv}$; merus of cheliped contains i spine in dorsa side and i spine in the ventral side; each propodus of the last four periopods contains ii spines in the dorsal side; dactylus of the 2nd periopod contains xviii spines in the dorsal side and iv spines in the ventral side; dactylus of 3rd periopod contains xviii spines in the dorsal side and ii spines in the ventral side; dactylus of the 4th periopod contains xiv spines in the dorsal side and iv spines in the ventral side; dactylus of 5th periopod contains $\mathrm{xx}$ spines in the dorsal side. 


\subsection{Species Remark with Sex and Color}

In the study crab species were remark with sex and color through observation. Species Calappa lophos (Herbst, 1782) is male [ $\left.\sigma^{\top}\right]$. (Figure 4(a)), ground yellowish beige yellow; purple spots on posterior carapace; transverse red stripes on postero lateral part. Species Criocarcinus superciliosus (Linnaeus, 1758) is unknown (Figure 4(b)), dorsal and ventral surface of carapace ash; cheliped ash and brown in color, but other legs are ash color only. Species Cardisoma armatum (Herklots, 1851) is male [ $\left.\sigma^{\top}\right]$ (Figure 4(c)), dorsal surface of carapace is chocolate and ventral surface is reddish-yellow in color. coxa is yellow in color in the dorsal side and brown in the ventral side; basi-ischium is yellow color in the dorsal and brown in the ventral side; merus is violet color in the dorsal and yellow in the ventral side; carpus is violet color in the dorsal and yellow in the ventral side; propodus and dactylus are yellowish in the dorsal side and in the ventral side of cheliped; coxa of last four periopods are reddish color in the dorsal and ventral side; basi-ischium, merus, carpus and propodus of last four periopods are chocolate in color in both dorsal and ventral side; dactylus of last four periopods are reddish in both dorsal and ventral sides.

Species Cardisoma carnifex (Herbst, 1796) is female [우 (Figure 4(d)), dorsal surface of carapace blackish-grey and ventral surface yellowish-white in color; coxa is yellowish-white in the dorsal side and yellowish-white in the ventral side.

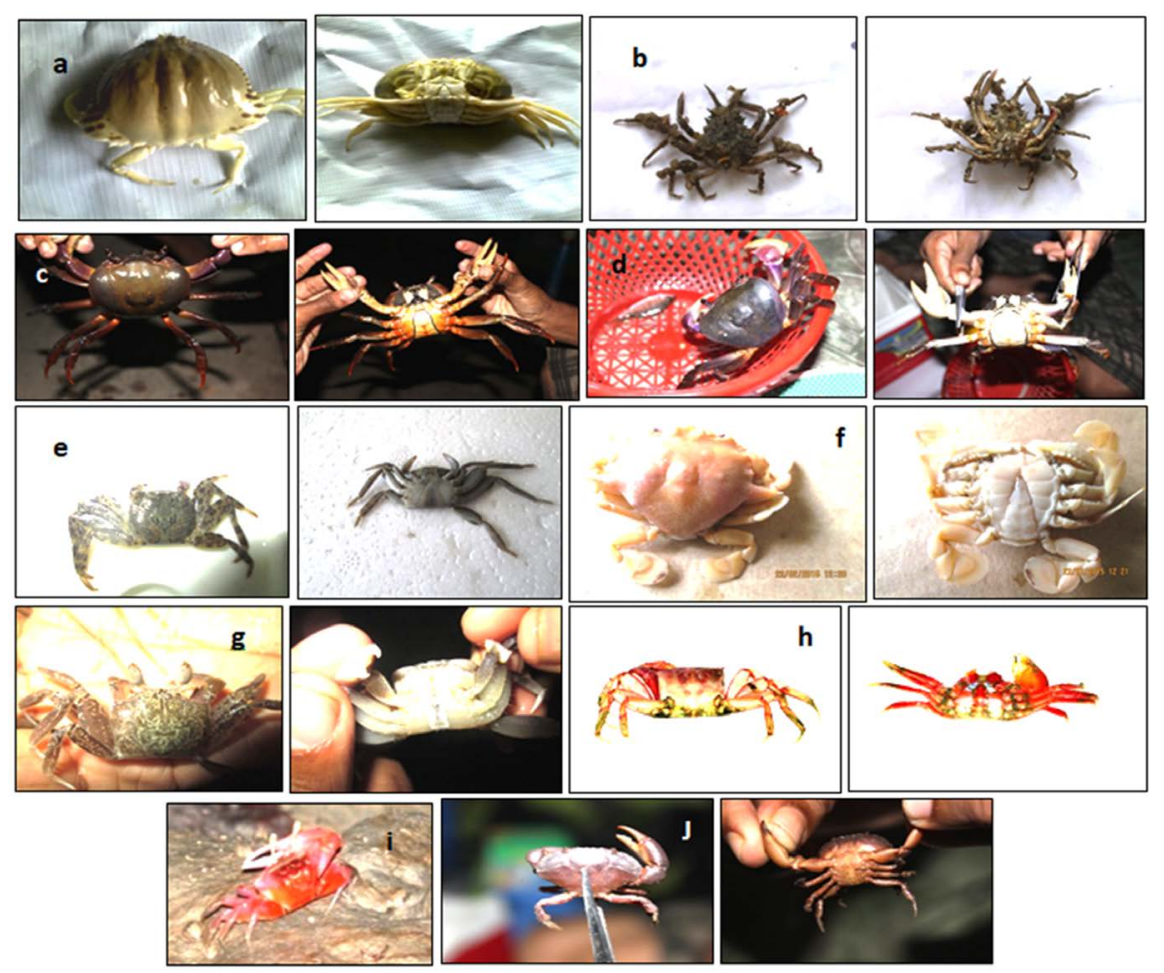

Figure 4. (a) Calappa lophos, (b) Criocarcinus superciliosus (c) Cardisoma armatum, (d) Cardisoma carnifex, (e) Grapsus albolineatus, (f) Matuta lunaris, (g) Ocypode pallidula, (h) Ocypode macrocera, (i) Uca rosea, (J) Panopeus lacustris, dorsal (left) and ventral (right) views. 
Basi-ischium is yellowish-white color in the dorsal side and pale white in the ventral side, merus is purple color in the dorsal side and whitish in the ventral side, carpus is purple color in the dorsal side and whitish in the ventral side, propodus is greenish-yellow color in the dorsal side and yellow in the ventral side, dactylus is yellow color in the dorsal side and yellow in the ventral side of cheliped; coxa is yellowish color in the dorsal side and yellowish in the ventral side. Species Grapsus albolineatus (Lamarck, 1818) is female [우 (Figure 4(e)), dorsal surface of carapace yellow and black; ventral surface off-white in color; all legs are brown black and off-white. Species Matuta lunaris (Forskal, 1775) is male $\left[\sigma^{7}\right]$ (Figure 4(f)), dorsal surface of the carapace is gray and yellow; and ventral surface is whitish; legs are cream in color. Species Ocypode pallidula (Jacquinot, 1846) (Linnaeus, 1758) is male [ $\left.\sigma^{\top}\right]$ (Figure 4(g)), dorsal surface of carapace ash and ventral surface off-white in color; legs are deep grayish and light grayish. Species Ocypode macrocera (Milne Edwards, 1852) is Male [o'] (Figure 4(h)), dorsal and ventral surfaces of carapace red in color. Species Uca rosea (Tweedie, 1937) is unknown (Figure 4(i)), dorsal surface of carapace red and ventral surface grayish; cheliped is combined of reddish and brownish, other legs are deep grayish and reddish. Species Panopeus lacustris (Desbonne, 1867) is Male [ $\left.\sigma^{\top}\right]$ (Figure 4(J)), dorsal surface of carapace coffee color and ventral surface brownish; cheliped coffee color, other legs are coffee and ash in color. Species Pseudosesarma bocourti (A. Milne-Edwards, 1869) is female [우] (Figure 5(a)), the dorsal surface of carapace is chocolate, dark, and yellowish. The ventral surface is black and yellowish in color; coxa and basi-ischium is reddish color in the dorsal side and yellowish in the ventral side, but merus is creamy in the ventral side, and carpus is whitish in the ventral side. Species Episesarma $s p$ (Latreille, 1803) is M ale [ $\left.\sigma^{\top}\right]$ (Figure 5(b)), the dorsal surface of carapace is deep grey; the ventral surface is whitish in color. Coxa, basi-ischium, merus, and carpus are grayish color in the dorsal side and yellowish in the ventral side. Propodus is reddish color in the dorsal side and off-white in the ventral side. Dactylus is white in color in the dorsal side, and white in the ventral side of the cheliped. The last four periopods are grayish in color in the dorsal side and yellowish in color in the ventral side.

Species Varuna litterata (Fabricius, 1798) is unknown (Figure 5(c)), the dorsal surface of the carapace is grayish, and the ventral surface is whitish. The cheliped is grayish and orange-grayish. The other legs are deep grayish and light grayish. Species Atergatis floridus (Linnaeus, 1767) is Male [o'] (Figure 5(d)), the dorsal surface of carapace is chocolate in color, and the ventral surface is yellowish. The cheliped is a combination of yellow, off-white, and black. The other legs are a combination of yellow and chocolate colors. Species Atergatis integerrimus (Lamarck, 1818) is Male [ $\left.\sigma^{\top}\right]$ (Figure 5(e)), the dorsal and ventral surfaces of the carapace are brown. The dactylus and propodus tip of the cheliped are black. The other legs are brown in color. Species Lophozozymus pictor (Fabricius, 1798) is Female [우 (Figure 5(f)), the dorsal surface of carapace is gray spotted red, and the ventral surface is also gray spotted red. The cheliped is 


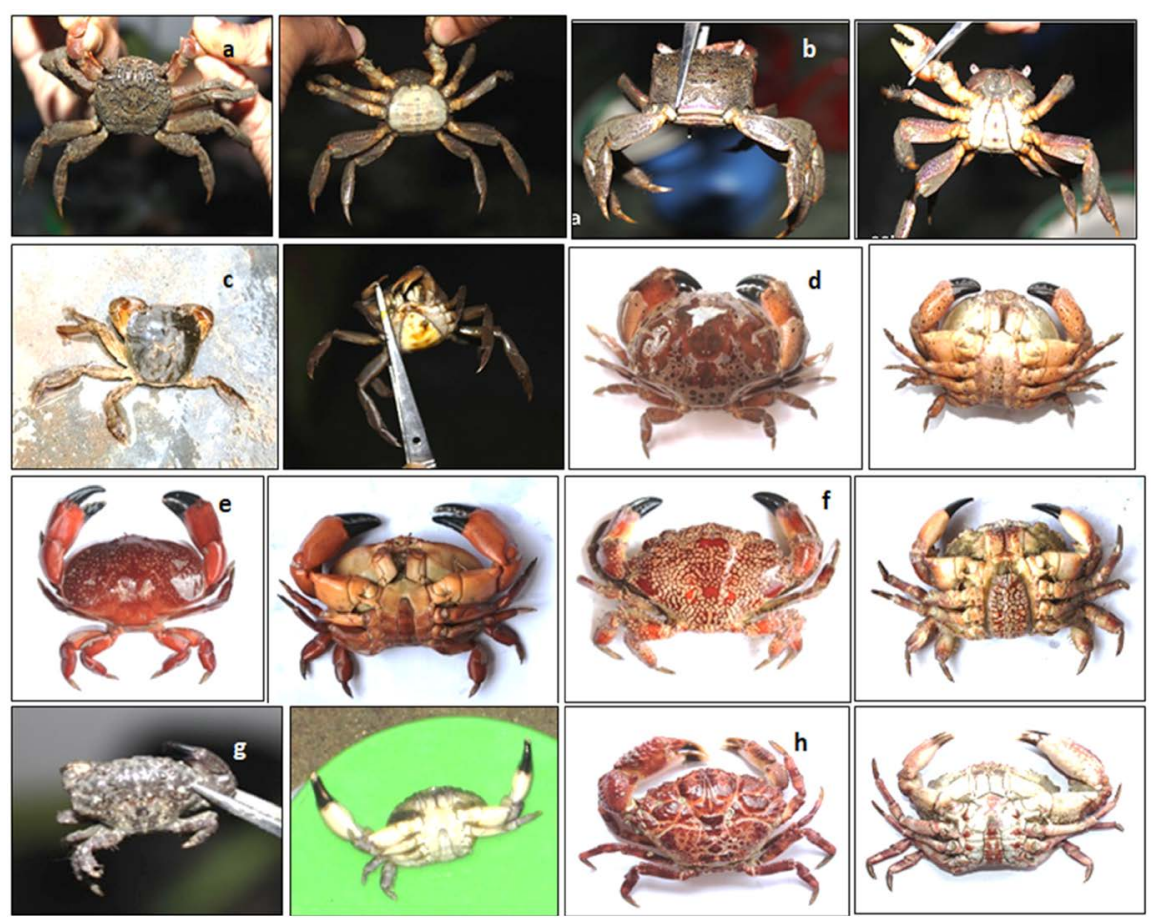

Figure 5. (a) Pseudosesarma bocourti, (b) Episesarma sp., (c) Varuna litterata, (d) Atergatis floridus, (e) Atergatis integerrimus, (f) Lophozozymus pictor, (g) Xantho poressa, (h) Zosymus aeneus. Dorsal (left), and Ventral (right) views.

a combination of white, red-white, chocolate, off-white, red-black, and black. The other legs are a combination of red-white, white, black-red, chocolate, and black. Species Xantho poressa (Olivi, 1792) is Male [ $\left.{ }^{\top}\right]$ (Figure 5(g)), the dorsal surface of carapace is grayish. The ventral surface is whitish. The cheliped is off-white and black, other legs are ash and off-white in color. Species Zosymus aeneus (Linnaeus, 1758) is M ale [ $\sigma^{\top}$ ] (Figure 5(h)), dorsal surface of carapace is reddish, and the ventral surface is off-white. The legs are off-white and reddish in color.

\subsection{Habitat Observation and Geographical Position}

In this study, Calappidae, Epialtidae, Gecarcinidae, Grapsidae, Matutidae, Ocypodidae, Panopeidae, Sesarmidae, Varunidae, and Xanthidae families included 18 species whereas ten species (C. superciliosus, C. armatum, C. carnifex, O. pallidula, P. lacustris, $P$. bocourti, A. floridus, L. pictor, X. poressa, $Z$. aeneus) newly found in this south east region as distribution and habitat. Seven species (C. $1 o-$ phos, G. albolineatus, M. lunaris, O. pallidula, O. macrocera, P. lacustris, X. poressa) were recorded from marine water habitat at site $1\left(20^{\circ} 39^{\prime} \mathrm{N}\right.$ and $\left.92^{\circ} 18^{\prime} \mathrm{E}\right)$; Five Species (C. armatum, C. carnifex, P. bocourti, Episesarma sp., V. litterata) were recorded from freshwater ditch is containing marsh habitat at site 2 $\left(20^{\circ} 38^{\prime} \mathrm{N}\right.$ and $92^{\circ} 19^{\prime} \mathrm{E}$ ) and Five species were (C. superciliosus, A. floridus, A. integerrimus, $L$. pictor, $Z$. aeneus) recorded from marine water habitat at site 3 $\left(20^{\circ} 36^{\prime} \mathrm{N}\right.$ and $\left.92^{\circ} 18^{\prime} \mathrm{E}\right)$ in Saint Martin's Island. Species Uca rosea recorded from 
brackishand freshwater habitat at site $4\left(22.3306^{\circ} \mathrm{N}\right.$ and $\left.89.1028^{\circ} \mathrm{E}\right)$ in Satkhira area, Bangladesh.

In the world, Bangladesh is the climatically vulnerable country for fisheries [28]. Researcher, twenty eight species reported from marine and freshwater [9] and most of the species used for human consumption [25] but still incomplete study with distinguishing morphometric and meristic character that has impact in the environment for long term sustain with other species. In crab culture have emerged employment and income opportunities [29] [30], but species introducer as distribution and character evolution is very few study happened in South East Asia. Species Criocarcinus superciliosus (Linnaeus, 1758) from china seas [31], Cardisoma armatum from Cape Verde and Senegal to Angola [32], Cardisoma carnifex (Herbst, 1796) from Kenyan mangrove swamp [33], Ocypode pallidula from Leigh Marine Reserve, New Zealand [34] but as distribution first time we find in marine water of Saint Martin's Island. Panopeus lacustris has been introduced in Hawaii in the 1950s [35], Indian River Lagoon [36], Brazil [37] but as distribution for the first time we found in marine water of Saint Martin's Island. Species Pseudosesarma bocourti under Sesarmidae family recorded from Japan [38], Kagoshima [39]; Thailand - Bangkok [40] but first time we found in marine water of Saint Martin's Island that is very extensive and important for ecology and environment to develop history and sustainable cultural in the coastal region.

Xanthidae family Species Atergatis floridus recorded from Sri Lanka [41], Hainan Island and Paracel Islands in China [42], Indian Pacific Ocean [43], Lophozozymus pictor fromnorth-eastern Taiwan, Thailand [44] Hainan Island in Singapore [41], China [42]; Xantho poressa reported from Bulgaria and Turkey coasts. [45], and Zosymus aeneus reported from Okinawa in Japan [46], Hainan Island and Paracel Islands in China [42], Durban in South Africa [47] but as distribution first time introduced with distinguishing character in this South East Asia region of Bangladesh. Habitat modification and introduction of crab species combined to cause loss of biodiversity occurred through anthropogenic activities. However, due to habitat loss, climatic conditions, poor transportation, limitation and lack of funds and resources many species unidentified in marine and freshwater of Bangladesh. Lack of studies on crustacean species identity and importance in South East Asia these results could be significant for next generation researchers around the world with Bangladesh. Therefore, biological investigation and an improved understanding of crab species by local people, fishermen regarding the importance of marine ecosystem of crabs in the South East Asia.

\section{Conclusion}

As a crucial investigation, a total of 18 crab species were recorded with morphometric and meristic characters. This original paper will be helpful for the further creation of suitable research plans to conserve marine crab populations, 
proper identification and investigation to enrich the brachyuran fauna of Bangladesh. All crab species have significant values in fishery, tourism, local economy, human health, socio-economic activities and biodiversity.

\section{Acknowledgements}

The study was supported by the Special Allocation Fund 2012-2013 of the Ministry of Science and Technology (SAF-MST-2013JnUZool00154BD), the Government of the People's Republic of Bangladesh. The authors sincerely thank Dr. Md. Saiful Islam for his valuable comments, providing laboratory, other instrumental facilities, and support. The authors express gratitude and regards to BCFRC and all the people in the field of different study sites who extended their cordial support during the study. We are really grateful to Dr. Kapiris Kostas, Research Director of HCMR, Athens, Greece for his valuable comments to improve the manuscript's quality.

\section{Conflicts of Interest}

The authors declare no conflict of interests for this research and paper.

\section{References}

[1] Bloch, C.P. and Klingbeil, B.T. (2016) Anthropogenic Factors and Habitat Complexity Influence Biodiversity but Wave Exposure Drives Species Turnover of a Subtropical Rocky Inter-Tidal Metacommunity. Marine Ecology, 37, 64-76. https://doi.org/10.1111/maec.12250

[2] Ng, P.K.L. Guinot, D. and Davie, P.J.F. (2008) Systema Brachyurorum: Part I. An Annotated Checklist of Extant Brachyuran Crabs of the World. The Raffles Bulletin of Zoology, 17, 1-286.

[3] Martin, J.W. and Davis, G.E. (2001) An Updated Classification of the Recent Crustacea. Natural History Museum of Los Angeles County. 132 p.

[4] Jose, J. (2015) Classification, Biodiversity and Conservation of Marine Crabs. Crustacean Fisheries Division, Central Marine Fisheries Research Institute, Kochi-682 018, 84-92.

[5] Sakai, K. (2020) Crabs of Japan, Marine Species Identification Portal. http://species-identification.org/species.php? species group $=$ crabs of japan\&menu en$\underline{\text { try=inleiding \&fbclid=IwAR3P0mpsGakkCV-w5TMloEveTq9YY862KWn1VBcX1c }}$ W6YtSfBeu/2v5zpiI

[6] Al-Maliky, T.H., Naser, M.D., Yasser, A.G., et al. (2016) New Record of the Grapsoid Crab Metaplax indica H. Milne-Edwards, 1852 (Decapoda: Brachyura: Thoracotremata) from the NW of the Arabian Gulf, Iraq. Arthropods, 5, 23-27.

[7] Varadharajan, D., Soundarapandian, P. and Pushparajan, N. (2013) The Global Science of Crab Biodiversity from Puducherry Coast, South East Coast of India. Arthropods, 2, 26-35.

[8] Zairion, A.A., Hakim, A. and Mashar, A. (2018) Diversity and Distribution of Dorippid Crabs (Brachyura: Dorippidae) in East Coast of Lampung, Indonesia. IOP Conference Series: Earth and Environmental Science, 149, Article ID: 012056. https://doi.org/10.1088/1755-1315/149/1/012056 
[9] Ahmed, A.T.A., Kabir, S.M.H., Ahmed, M., Rahman, A.K.A., Haque, E.U., Ahmed, Z.U., Begum, Z.N.T, Hassan, M.A. and Khondker, M. (2008) Encyclopedia of Flora and Fauna of Bangladesh. Arthropoda: Crustacea. Asiatic Society of Bangladesh, Dhaka, 18, 155-202.

[10] Rahman, M.A., Rahman, M.M., Ahmed, A.T.A., Mollah, A.R. and Hossain, M.A. (2008) A Survey on the Diversity of Freshwater Crabs in Ome Wetland Ecosystems of Bangladesh. International Journal Sustainable Crop Production, 3, 10-17.

[11] Kamal, A.H.M. and Khan, M.A.A. (2009) Coastal and Estuarine Resources of Bangladesh: Management and Conservation Issues. Maejo International Journal Science Technology, 3, 313-342.

[12] Chowdhury, S.H. and Hafizuddin, A.K.M. (1991) Crab Fauna of Bangladesh. Part 1. Some Marine Crabs from the Bay of Bengal. Chittagong University Studies. Science, 15, 65-77.

[13] Ahyong, S.T. and Ng, P.K.L. (2005) Review of Durckheimia and Xanthasia, with Descriptions of Two New Genera (Decapoda: Brachyura: Pinnotheridae). Journal of Crustacean Biology, 25, 116-129. https://doi.org/10.1651/C-2504

[14] Thoma, B.P., Guinot, D. and Felder, D.L. (2014) Evolutionary Relationships among American Mud Crabs (Crustacea: Decapoda: Brachyura: Xanthoidea) Inferred from Nuclear and Mitochondrial Markers, with Comments on Adult Morphology. Zoological Journal of the Linnean Society, 170, 86-109. https://doi.org/10.1111/zoj.12093

[15] Alcock, A.W. (1896) Materials for a Carcinological Fauna of India. No. 2. The Brachyura Oxystomata. Journal of the Asiatic Society of Bengal, 65, 134-296.

[16] Deb, M. (1999) Crustacea: Decapoda: Crabs. In: Fauna Series 3, Zoological Survey of India, Calcutta, 345-403.

[17] Davie, P.J.F. (2002) Crustacea: Malacostraca: Eucarida (Part 2): Decapoda Anomura, Brachyura. Vol. 19.3B. CSIRO Publishing, Melbourne, xiv, 641 p.

[18] Gary, C.B.P. and Shane, T.A. (2004) Marine Decapod Crustacea of Southern Australia: A Guide to Identification. CSIRO Publishing, Collingwood.

[19] Michel, E.H. and Jose, L.C. (2003) A New Species of Loxorhynchus Stimpson (Decapoda, Majoidea, Pisidae) from the Pacific Coast of Mexico. Crustaceana, 76, 103-113. https://doi.org/10.1163/156854003321672863

[20] Ng, P.K.L. (1998) Crabs. In: Carpenter, K.E. and Niem, V.H., Eds., The Living Marine Resources of the Western Central Pacific. Cephalopods, Crustaceans, Holothurians and Sharks, FAO Species Identification Guide for Fishery Proposes, FAO, Rome, Vol. 2, 1045-1155.

[21] Ng, P.K.L. (2004) Crustacea: Decapoda, Brachyura. In: Yule, C.M. and Yong, H.S., Eds., Freshwater Invertebrates of the Malaysian Region, Academy of Sciences Malaysia, Kuala Lumpur, 311-336.

[22] Verrill, A.E. (1908) Decapod Crustacea of Bermuda I. Brachyura and Anomura. Their Distribution, Variations, and Habits. Transactions of the Connecticut Academy of Arts and Sciences, 13, 299-474.

[23] Vannini, M. and Innocenti, G. (2000) Research on the Coast of Somalia. Portunidae (Crustacea Brachyura). Tropical Zoology, 13, 251-298.

https://doi.org/10.1080/03946975.2000.10531136

[24] Rodriguez, I.T., Hernandez, G. and Felder, D.L. (2005) Review of the Western Atlantic Porcellanidae (Crustacea: Decapoda: Anomura) with New Records, Systematic Observations, and Comments on Biogeography. Caribbean Journal of 
Science, 41, 544-582.

[25] Shafi, M. and Quddus, M.M.A. (1982) Bangladesher Matsho Shampad (in Bangla). Bangla Academy, Dhaka, 369-396.

[26] Siddiqui, M.Z.H. and Zafar, M. (2002) Crabs in the Chakaria Sundarban Area of Bangladesh. J. Nat. Ocean Marit. Inst., 19, 61-77. https://portals.iucn.org/library/sites/library/files/documents/RL-549.3-003-v.6.pdf

[27] Trivedi, J.N. and Vachhrajani, K.D. (2013) First Record of Two Porcellanid Crabs from Gujarat State, India (Crustacea: Decapoda: Porcellanidae). Journal of the Marine Biological Association of India, 55, 55-58. https://doi.org/10.6024/jmbai.2013.55.1.01756-09

[28] IPCC (2007) Climate Change 2007, Impacts, Adaptation and Vulnerability: Summary for Policymakers. Working Group II Contribution to the Intergovernmental Panel on Climate Change Fourth Assessment Report. IPCC, Geneva.

[29] Hussain, M.G., Failler, P., Al Karim, A. and Alam, M.K. (2018) Major Opportunities of Blue Economy Development in Bangladesh. Journal of the Indian Ocean Region, 14, 88-99. https://doi.org/10.1080/19480881.2017.1368250

[30] Rahman, M.M., Islam, M.A., Haque, S.M. and Wahab, A. (2017) Mud Crab Aquaculture and Fisheries in Coastal Bangladesh. World Aquaculture, 48, 47-52.

[31] Liu, J.Y. (2008) Checklist of Marine Biota of China Seas. China Science Press, Beijing, $1267 \mathrm{p}$.

[32] Fischer, W., Bianchi, G. and Scott, W.B. (1981) True Crabs. 6: pag.var. In FAO Species Identification Sheets for Fishery Purposes. Eastern Central Atlantic (Fishing Areas 34, 47; in Part). Canada Funds-in-Trust. Ottawa, Department of Fisheries and Oceans Canada, by Arrangement with the Food and Agriculture Organization of the United Nations, 1-7: pag.var.

[33] Berti, R., Cannicci, S., Fabbroni, S. and Innocenti, G. (2008) Notes on the Structure and the Use of Neosarmatium meinerti and Cardisoma carnifex Burrows in a Kenyan Mangrove Swamp (Decapoda Brachyura). Ethology Ecology and Evolution, 20, 101-113. https://doi.org/10.1080/08927014.2008.9522531

[34] Colin, L.M. (2009) New Records of Crabs (Decapoda: Brachyura) from the New Zealand Region, Including a New Species of Rochinia A. Milne-Edwards, 1875 (Majidae), and a Revision of the Genus Dromia Weber, 1795 (Dromiidae). Zootaxa, 2111, 1-66. https://doi.org/10.11646/zootaxa.2111.1.1

[35] Abele, L.G. and Kim, W. (1986) An Illustrated Guide to the Marine Decapod Crustaceans of Florida. State of Florida Department of Environmental Regulation Technical Series Vol. 8, No. 1, 225.

[36] Manning, R.B. and Hart Jr., C.W. (1989) The Occurrence of Panopeus lacustris Schramm in Marine caves of Bermuda. Crustaceana, 57, 313-315. https://doi.org/10.1163/156854089X00662

[37] Filho, L.G.A.S., Santos, S.G.A.V., Góes, J.M. and Fernandes-Góes, L.C. (2017) Population Biology of Panopeus lacustris Desbonne 1867 (Brachyura: Panopeidae) in Piaui Coastal, Brazil. Arquivos de Ciências do Mar Fortaleza, 50, 53-71. https://doi.org/10.32360/acmar.v50i2.31146

[38] Targioni Tozzetti, A. (1877) Crostacei Brachyuri e Anomuri. In: Zoologia del viaggio intorno al Globo della R. Pirocorvetta Magenta durante gli anni 1865-1868. Pubblicazioni del R. Istituto di Studi superiore pratici e di Perfezionamento in Firenze. Sezione di Scienze fisiche e naturali, 1: i-xxix, 1-257, pls 1-12.

[39] Urita, T. (1926) A Check-List of Brachyura Found in Kagoshima Prefecture, Japan. 
Tshingtao Times: i-iii, 1-41, 1 map.

[40] Milne Edwards, A. (1869) Notes sur quelques nouvelles espèces de genre Sesarma. Nouvelles archives du Muséum national d'Histoire naturelle, Paris, Vol. 5, 25-31.

[41] Alcock, A.W. (1898) Materials for a Carcinological Fauna of India. No. 3. The Brachyura Cyclometopa. Part 1. The Family Xanthidae. Journal of the Asiatic Society of Bengal, Calcutta, 67, 67-233.

[42] Dai, A. and Yang, S. (1991) Crabs of the China Seas, i-iv, 1-608, figs 1-295, pls 1-74. China Ocean Press, Beijing and Springer-Verlag, Berlin.

[43] Ng, P.K.L. and Davie, P.S.F. (2007) On the Identity of Atergatis floridus (Linnaeus, 1767) and Recognition of Atergatis ocyroe (Herbst, 1801) as a Valid Species from the Indian Ocean (Crustacea: Brachyura: Xanthidae). The Raffles Bulletin of Zoology, 16, 169-175.

[44] Ng, P.K.L. and Chia, D.G.B. (1997) Lophozozymus Erinnyes, a New Species of Poisonous Crab from Australia, with Notes on L. pictor (Fabricius, 1798), L. incisus (H. Milne Edwards, 1834) and L. edwardsi (Odhner, 1925) (Crustacea: Decapoda: Brachyura: Xanthidae). The Raffles Bulletin of Zoology, 45, 419-443.

[45] Kobjakova, Z.I. and Dolgopolskaya, M.A. (1969) Otriad Desiatinogie-Decapoda. Opredelitel fauny Chernogo i Azovskogo morey. Tom 2. Svobodnozhivuschie bespozvonochnye. Rakoobraznye. [Order decapods-Decapoda. The Field Guide for the Black and Azov Seas. Volume 2. Free-Living Invertebrates. Crustaceans.]. Naukova Dumka, Kiev, 207-306, pls. 1-7. (In Russian)

[46] Stimpson, W. (1907) Report on the Crustacea (Brachyura and Anomura) Collected by the North Pacific Exploring Expedition, 1853-1856. Smithsonian Miscellaneous Collections, Vol. 49(1717), Smithsonian Institution, Washington DC, 1-240. https://doi.org/10.5962/bhl.title.51448

[47] Stebbing, T.R.R. (1917b) The Malacostraca of Durban Bay. Annals of Durban Museum, 1, 435-450. 